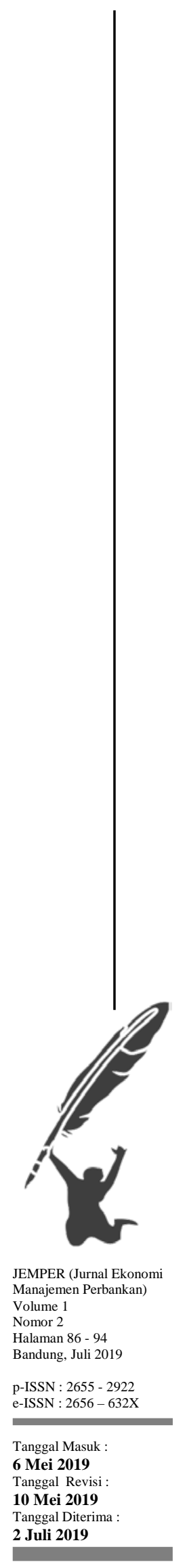

JEMPER(Jurnal Ekonomi Manajemen Perbankan)

http://jurnal.usbypkp.ac.id/index.php/jemper

\title{
PENGARUH CAR, LDR DAN NPL TERHADAP PROFITABILITAS PADA BANK YANG TERDAFTAR DI BURSA EFEK INDONESIA (BEI) (STUDI KASUS PT.BANK BUKOPIN TBK TAHUN 2005-2018)
}

\author{
Sri Devi Apriani ${ }^{1}$ \\ Universitas Sangga Buana YPKP Bandung \\ srideviapriani97@gmail.com \\ Lousiani Mansoni ${ }^{2}$ \\ Universitas Sangga Buana YPKP Bandung \\ lousianimansoni@gmail.com
}

\begin{abstract}
The purpose of this study is to analyze the effect of the CAR, LDR, and NPL on the Profitability of Banks Listed on the Indonesia Stock Exchange. The sample in this study is PT Bank Bukopin for 13 years, from 2005 to 2018. Data contained in this study are secondary data, namely the empirical method with a descriptive and verification analysis approach. The data analysis technique used is multiple linear regression analysis with the help of the program Eviews 9 and SPSS 16 so as to get a comprehensive picture of the relationship between variables one with other variables. Hypothesis testing uses $t$ statistics to test the regression coefficients partially and F-statistics to test the significance of the effects together with a significance level of 5\%. In addition, classic assumptions were also carried out including normality tests, multicollinearity tests, heteroscedasticity tests, and autocorrelation tests. The results of this study are that the $C A R, L D R$, and NPL variables do not significantly affect ROA partially at a significance level of less than 5\%. And the results of simultaneous regression analysis show that CAR, LDR, and NPL together influence ROA. The predictive ability of the three variables on ROA is $56 \%$ while the remaining $44 \%$ the influence of other factors not included inthe study.
\end{abstract}

Keywords: CAR, LDR, NPL, and ROA

\begin{abstract}
Abstrak
Tujuan penelitian ini yaitu menganalisis Pengaruh CAR, LDR, dan NPL Terhadap Profitabilitas Bank Yang Terdaftar di BEI. Sampel pada penelitian ini yaitu PT Bank Bukopin selama 13 tahun yaitu dari tahun 2005 - 2018. Data yang terdapat pada penelitian ini merupakan data sekunder dengan metode empiris dengan pendekatan analisis deskriptif dan verifikatif. Teknik analisis data menggunakan analisis regresi linear berganda dengan bantuan program Eviews 9 sehingga mendapatkan gambaran secara menyeluruh mengenai hubungan antara variabel satu dengan variabel yang lainnya. Uji hipotesis menggunakan t-statistik untuk menguji koefisien regresi secara parsial serta Fstatistik untuk menguji keberartian pengaruh secara bersama-sama dengan tingkat signifikansi 5\%. Serta dilakukan uji asumsi klasik diantaranya uji normalitas, uji multikolinearitas, uji heteroskedastisitas dan uji autokorelasi. Hasil penelitian ini adalah bahwa variabel CAR, LDR, dan NPL tidak berpengaruh secara signifkan terhadap ROA secara parsial pada level of significance kurang dari 5\%. Sedangkan hasil analisis regresi secara simultan diperoleh bahwa CAR, LDR, dan NPL secara bersama-sama mempengaruhi ROA. Kemampuan prediksi dari ketiga variabel tersebut terhadap ROA sebesar 56\% sedangkan sisanya 44\% pengaruh dari faktor lain yang tidak termasuk dalam penelitian.
\end{abstract}

Kata kunci: CAR, LDR, NPL, and ROA 


\section{PENDAHULUAN}

Bank sebagai suatu lembaga keuangan atau perusahaan yang bergerak di bidang keuangan, yakni kegiatan utama bank yaitu menghimpun dan menyalurkan dana dari masyarakat serta memberikan jasa-jasa bank yang lain. Di negara-negara maju, bank menjadi kebutuhan utama masyarakat setiap kali bertransaksi. Di Negara Indonesia, bank adalah bagian dari sektor keuangan yang diharapkan dapat merubah kondisi perekonomian ke arah yang lebih baik, karena bank sebagai penggerak roda perekonomian.

Bank pada dasarnya berorientasi pada perolehan keuntungan atau profit oriented berdasarkan prinsip dari bunga yang telah ditentukan. Besar kecilnya bunga simpanan berpengaruh pada besar kecilnya bunga kredit. Semakin besar atau semakin mahal bunga simpanan, maka bunga pinjaman akan semakin besar pula dan juga sebaliknya. Selain bunga simpanan, besar kecilnya bunga pinjaman juga dipengaruhi oleh keuntungan yang diambil, biaya operasi yang dikeluarkan, cadangan risiko, kredit macet, serta pengaruh lainnya. (Kasmir, 2015:14).

Faktor yang berpengaruh terhadap ROA diantaranya CAR yang merupakan rasio yang digunakan untuk mengukur kemampuan bank dalam menyediakan dana yang digunakan untuk aktivitas operasional bank. CAR minimun yang harus dipenuhi Bank sebesar 8\%. LDR yaitu seberapa besar dana pihak ketiga di Bank Umum dilepaskan ke perkreditan. Standar LDR yaitu 78\% - 92\%. NPL merupakan presentase jumlah kredit bermasalah. NPL maksimum pada bank yaitu $5 \%$.

\begin{tabular}{|c|c|c|c|c|}
\hline Tahun & CAR & LDR & NPL & ROA \\
\hline 2005 & 13,08 & 68,38 & 3,37 & 2,09 \\
\hline 2006 & 15,79 & 58,86 & 3,71 & 1,85 \\
\hline 2007 & 12,84 & 65,26 & 3,57 & 1,63 \\
\hline
\end{tabular}

Sumber : Laporan Keuangan Tahunan PT Bank Bukopin Tbk

Berdasarkan tabel tersebut, adanya pergerakan CAR, LDR dan NPL tetapi tidak diikuti oleh kenaikan ROA. Sehingga berdasarkan latar belakang diatas, maka perlu diadakan penelitian dengan judul :

"Pengaruh CAR, LDR, dan NPL terhadap Profitabilitas pada Bank yang terdaftar di BEI. (Studi kasus PT. Bank Bukopin Tbk tahun 2005-2018).

\section{LITERATUR}

\section{Hasil Penelitian Terdahulu}

Berdasarkan penelitian Mismiwati (2016) yaitu Hasil Penelitian Menunjukkan Secara Simultan CAR, NIM, BOPO, LDR dan NPL berpengaruh terhadap ROA. Sedangkan secara parsial CAR, NIM dan NPL Tidak Berpengaruh Terhadap ROA, sedangkan BOPO dan LDR Berpengaruh Signifikan Terhadap ROA.

Berdasarkan penelitian Muttaqin (2017) hasil uji F menunjukan bahwa variabel CAR, BOPO, NPL dan LDR berpengaruh signifikan terhadap ROA. Sedangkan secara Parsial menunjukan bahwa CAR dan NPL tidak berpengaruh secara signifikan sedangkan BOPO dan LDR berpengaruh signifikan terhadap ROA pada Bank Konvensional di Indonesia. 
Penelitian yang dilakukan Hasdillah (2017) hasil Uji F (simultan) menunjukkan yaitu variabel LDR, NPL, NIM dan CAR berpengaruh signifikan terhadap ROA dan hasil uji t (parsial) menunjukkan LDR, NPL, dan CAR tidak berpengaruh signifikan, sedangkan NIM berpengaruh positif dan signifikan, terhadap ROA pada Bank Pembangunan Daerah Kalimantan Timur.

Penelitian yang dilakukan Bernardin (2016), hasil penelitian bahwa Uji Parsial CAR berpengaruh signifikan terhadap ROA, dan LDR tidak berpengaruh signifikan terhadap ROA. sedangkan Uji Simultan menunjukkan bahwa CAR dan LDR berpengaruh signifikan terhadap ROA.

Penelitian yang dilakukan Shidieq (2015), Hasil penelitian menunjukkan bahwa secara parsial variabel LDR berpengaruh positif terhadap ROA, variabel GCG dan BOPO berpengaruh negatif terhadap ROA, serta variabel NPL dan CAR tidak berpengaruh terhadap ROA. sedangkan semua variabel berpengaruh secara simultan terhadap ROA.

Penelitian yang dilakukan Batari dan Hartono (2018), hasil penelitian uji t memperoleh hasil bahwa ukuran bank berpengaruh terhadap profitabilitas, CAR dan NPL berpengaruh signifikan terhadap profitabilitas, dan LDR tidak berpengaruh terhadap profitabilitas.

Sedangkan secara simultan ukuran perusahaan, CAR, LDR dan NPL berpengaruh terhadap profitabilitas.

\section{BANK}

Menurut Kasmir, (2015:12) Bank secara sederhana dapat diartikan Bank sebagai Lembaga Keuangan yang kegiatan utamanya adalah menghimpun dana dari masyarakat dan menyalurkannya kembali dana tersebut ke masyarakat serta memberikan jasa bank lainnya.

\section{CAR}

Menurut Atmoko, dkk, (2018) CAR adalah suatu indikator untuk melihat kesehatan permodalan bank, untuk mengukur kecukupan modal yang dimiliki bank untuk menunjang aktiva yang mengandung atau menghasilkan risiko misalnya pembiayaan yang diberikan.

\section{LDR}

Menurut Herman, (2016) LDR merupakan rasio yang mengukur kemampuan bank untuk memenuhi kewajiban yang harus dipenuhi. Sehingga semakin tinggi LDR maka laba bank semakin meningkat (dengan asumsi bank tersebut mampu menyalurkan kreditnya dengan efektif), dengan meningkatnya laba bank, maka kinerja bank juga meningkat. Dengan demikian besar-kecilnya rasio LDR suatu bank akan mempengaruhi kinerja bank tersebut.

NPL

Herman, 2019 NPL yang sering disebut kredit bermasalah dapat diartikan sebagai pinjaman yang mengalami kesulitan pelunasan akibat adanya faktor kesenjangan atau faktor eksternal di luar kemampuan kendali debitur. Dampak dari rasio NPL yang tidak wajar salah satunya adalah hilangnya kesempatan memperoleh income (pendapatan) dari kredit yang diberikan, sehingga mengurangi perolehan laba. 


\section{ROA}

Maulana, dkk, 2018 ROA adalah rasio yang menunjukan hasil (return) atas jumlah aktiva yang digunakan dalam perusahaan. Selain itu, ROA memberikan ukuran yang lebih baik atas profitabilitas perusahaan karena menunjukan efektivitas manajemen dalam menggunakan aktiva untuk memperoleh pendapatan.

\section{METODE PENELITIAN \\ Rancangan Penelitian}

Metode yang digunakan dalam penelitian ini adalah metode deskriptif dimana penelitian yang dilakukan terhadap variabel yang datanya sudah ada tanpa proses manipulasi (data masa lalu).Penelitian ini dilakukan untuk mengetahui rasio keuangan yang mempengaruhi kinerja bank serta memberikan saran berupa alternatif dalam rangka meningkatkan kinerja Bank Bukopin.

\section{Populasi dan Teknik Pengumpulan Data}

Dalam penelitian ini menggunakan populasi yaitu Laporan Keuangan Bank Bukopin dan menggunakan teknik field research yaitu penelitian secara langsung dengan data yang diperoleh adalah dokumentasi terkait pada data bank dari tahun 2005-2018.

\section{Variabel Penelitian}

Berikut adalah variabel dalam penelitian ini :

1) Variabel dependen (Y) berupa kinerja Bank Bukopin yang diukur dengan Return On Assets (ROA).

2) Variabel independen berupa rasio keuangan CAR (X1), LDR (X2), NPL (X3).

\section{Teknik Analisis Data}

\section{Analisis Statistik Deskriptif}

Statistik deskriptif yang ditujukan untuk menganalisis data dengan mendeskripsikan data yang telah terkumpul sebagaimana adanya tanpa bermaksud membuat kesimplan secara umum (Sugiyono, 2008).

\section{Analisis Statistik}

Pengujian penelitian ini dilakukan dengan uji secara statistik dengan menggunakan :

1) Pengujian Asumsi Klasik

Karena data yang digunakan adalah data sekunder, maka untuk menentukan ketepatan model perlu dilakukan pengujian atas beberapa asumsi klasik untuk memenuhi asumsi dasar. Meliputi uji, normalitas, multikolinearitas, autokorelasi, dan heteroskedatisitas.

2) Analisis Regresi Linier Berganda

3) Koefisien Korelasi

4) Koefisien Determinasi

\section{Pengujian Hipotesis}

1) Uji Signifikansi Parsial (Uji Statistik t)

2) Uji Signifikansi Simultan (Uji Statisitk F) 


\section{HASIL DAN PEMBAHASAN}

\section{Analisis Deskriptif}

Hasil analisis Deskriptif terdapat pada Tabel 2, menunjukkan bahwa jumlah observasi data penelitian yang digunakan selama 14 tahun pengamatan yaitu dari tahun 2005-2018. Hasil analisis pada tabel mendeskripsikan gambaran umum data yang digunakan secara keseluruhan.

Tabel 2. Uji Statistik Deskriptif

\begin{tabular}{lccccc}
\hline & Obs & Mean & Max & Min & Std.Dev \\
\hline CAR & 14 & 13.41 & 18.45 & 10.52 & 2.11 \\
\hline LDR & 14 & 78.30 & 86.18 & 58.86 & 8.78 \\
\hline NPL & 14 & 3.44 & 6.37 & 1.51 & 1.42 \\
\hline ROA & 14 & 1.34 & 2.09 & 0.09 & 0.66 \\
\hline (Eviews 9, data diolah) & & &
\end{tabular}

\section{Analisis Statistik}

Sebelum dilakukan pengujian hipotesis, maka data yang telah diperoleh dalam penelitian ini akan diuji terlebih dahulu untuk memenuhi asumsi dasar dengan uji asumsi klasik.

\section{Tabel 3. Hasil Uji Normalitas}

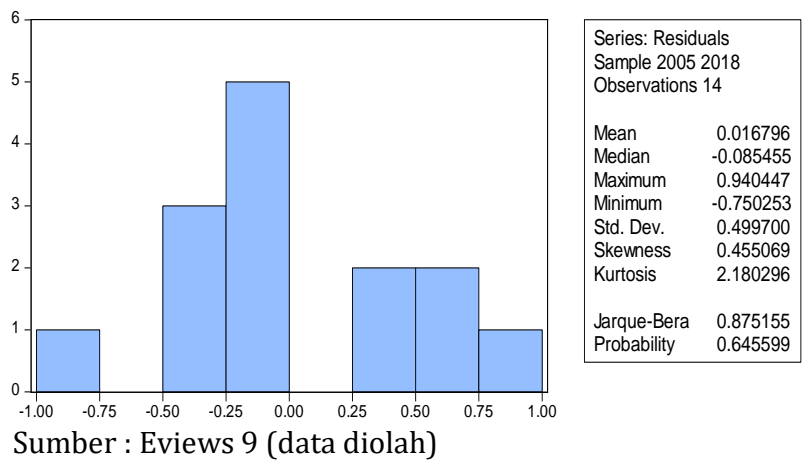

Hasil uji normalitas terdapat pada Tabel 3, dapat disimpulkan bahwa besarnya Nilai Jarque-Bera sebesar 0.875155 dengan probabilitas 0.645599. Dan nilai Probability dari Jarque-Bera sebesar 0.645599 lebih besar dari Alpha 0.05. Artinya bahwa residual berdistribusi normal, sehingga asumsi klasik tentang kenormalan di model fixed effect telah terpenuhi.

\section{Tabel 4. Uji Multikolinieritas}

\begin{tabular}{cc}
\hline Variable & Centered VIF \\
\hline CAR & 1.240945 \\
\hline LDR & 1.042401 \\
\hline NPL & 1.2096949 \\
\hline C & NA \\
\hline Sumber : Eviews 9 (data diolah)
\end{tabular}

Nilai Contered Variance Inflation Factor (VIF) menunjukkan hal yang sama, yaitu tidak ada satupun variabel independen yang memiliki nilai VIF lebih dari 10, sehingga tidak ada multikolonieritas antar variabel independen dalam model regresi. 
Tabel 5. Uji Autokorelasi

\begin{tabular}{lcll}
\hline F-statistic & $\mathbf{1 . 3 8 7 6 8 2}$ & $\begin{array}{l}\text { Prob. } \\
\text { F(2.9) }\end{array}$ & $\mathbf{0 . 2 9 8 3}$ \\
\hline $\begin{array}{l}\text { Obs*R- } \\
\text { squared }\end{array}$ & 3.286674 & $\begin{array}{l}\text { Prob. Chi- } \\
\text { Square(2) }\end{array}$ & 0.1933 \\
\hline (Eviews 9, data diolah) & \multicolumn{2}{l}{} &
\end{tabular}

Standarisasi uji autokorelasi yaitu $>0.05$. Nilai yang didapat yaitu $0.1933>0.05$. Berarti bahwa dalam penelitian ini tidak terdapat masaah autokerasi serial.

Tabel 6. Uji Heteroskedastisitas

\begin{tabular}{|c|c|c|c|}
\hline F-statistic & 5.492513 & Prob. F(9,4) & 0.0581 \\
\hline $\begin{array}{l}\text { Obs*R- } \\
\text { squared }\end{array}$ & 12.95195 & $\begin{array}{l}\text { Prob. Chi- } \\
\text { Square (9) }\end{array}$ & 0.1648 \\
\hline $\begin{array}{l}\text { Scaled } \\
\text { explained SS }\end{array}$ & 6.426666 & $\begin{array}{l}\text { Prob. Chi- } \\
\text { Square (9) }\end{array}$ & 0.6966 \\
\hline
\end{tabular}

Tabel 7. Uji Regresi Linear Berganda

\begin{tabular}{cc}
\hline Variable & Coefficient \\
\hline $\mathbf{C}$ & 3.397194 \\
\hline CAR & 0.084946 \\
\hline LDR & -0.032089 \\
\hline NPL & -0.199778 \\
\hline (Eviews 9, data diolah)
\end{tabular}

Dari tabel diatas dapat disusun persamaan :

ROA=3.397194+0.084946CAR-0.032089LDR-0.199778NPL

Sehingga ROA mempunyai nilai 3.397194 apabila variabel independen konstan. Dan apabila CAR mengalami kenaikan 1 satuan maka ROA akan naik sebesar 0.084946, sedangkan LDR ketika turun 1 satuan maka nilai ROA sebesar pada tabel 7 tersebut.

Tabel 8. Koefisien Korelasi

\begin{tabular}{cc}
\hline & ROA \\
\hline CAR & 0.517 \\
\hline LDR & -0.456 \\
\hline NPL & $-0,525$ \\
\hline Sumber : SPSS (data diolah)
\end{tabular}

Sumber : SPSS (data diolah)

Diperoleh nilai dengan tingkat hubungan bahwa CAR, LDR, dan NPL terhadap ROA termasuk dalam kategori sedang, karena berada pada tingkat koefisien korelasi 0.40-0.599.

\section{Tabel 9. Koefisien Determinasi}

\begin{tabular}{ccc}
\hline $\begin{array}{c}\text { R- } \\
\text { squared }\end{array}$ & $\begin{array}{c}\text { Adjusted R- } \\
\text { squared }\end{array}$ & $\begin{array}{c}\text { S.E. of } \\
\text { regression }\end{array}$ \\
\hline $\mathbf{0 . 5 6 3 3 4 9}$ & 0.432353 & 0.495098
\end{tabular}

Sumber : Eviews 9 (data diolah) 
Dari hasil yang terdapat pada tabel 9, nilai R-squared diperoleh sebesar 0.563349, yang berarti bahwa yang dipengaruhi oleh variabel independen (CAR, LDR dan NPL) sebesar 56\% sedangkan sisanya dipengaruhi oleh faktor lain diluar penelitian.

Tabel 10. Hasil Uji Parsial (Uji t)

\begin{tabular}{lcc}
\hline \multicolumn{1}{c}{ Variable } & t-Statistic & Prob \\
\hline C & 1.805235 & 0.1012 \\
\hline CAR & 1.171830 & 0.2684 \\
\hline LDR & -2.009903 & 0.0722 \\
\hline NPL & -1.882906 & 0.0891 \\
\hline Sumber : Eviews 9 (data diolah) &
\end{tabular}

Dari tabel diatas, diperoleh hasil t-statistic yang bernilai positif tidak sesuai kriteria pengujian yaitu harus $>\mathrm{t}$ tabel, sedangkan yang bernilai negatif harus $<\mathrm{t}$ tabel. Nilai $\mathrm{t}$ tabel sebesar 2.26216. Dan nilai prob tidak memenuhi tingkat signifikansi $<0.05$. Sehingga dapat disimpulkan bahwa secara parsial tidak ada satupun variabel independen yang berpengaruh secara signifikan terhadap profitabilitas.

Tabel 11. Hasil Uji Simultan (Uji F)

\begin{tabular}{cc}
\hline F-statistic & $\mathbf{4 . 3 0 0 5 2 5}$ \\
\hline Prob (F-statistic) & 0.034234 \\
\hline Sumber : Eviews 9 (data diolah)
\end{tabular}

Hasil output diatas menunjukkan nilai F-statistic $>$ F tabel sudah sesuai dengan kriteria pengujian, yaitu sebesar $0.034234>3.86$. Dan nilai prob diperoleh hasil sesuai tingkat signifikansi $<0.05$, yaitu sebesar $0.034234<0.05$. Maka dapat disimpulkan bahwa secara simultan variabel-variabel independen berpengaruh terhadap profitabilitas.

\section{Pengaruh CAR Terhadap ROA}

Berdasarkan hasil penelitian terbukti bahwa variabel CAR tidak berpengaruh signifikan terhadap ROA sehingga Ho diterima.

Hasil penelitian ini juga tidak sesuai teori yang menyatakan bahwa semakin tinggi CAR mengindikasikan bahwa bank telah mempunyai modal yang baik dalam menunjang kebutuhannya

Ketidaksesuaian antara dengan teori ini kemungkinan disebabkan CAR yang tinggi dapat mengurangi kemampuan bank dalam melakukan ekspansi usahanya karena semakin besarnya cadangan modal yang digunakan untuk menutupi risko kerugian. Sehingga kondisi ini menandakan bahwa bank tidak menggunakan seluruh potensi modalnya untuk meningkatkan profitabilitas bank, dengan kata lain banyak dana yang hanya ditampung begitu saja tanpa disalurkan kepada pihak ketiga atau kredit.

Hasil penelitian ini sejalan dengan penelitian yang dilakukan oleh Husein Fajri Muttaqin (2017) dan Hasdillah (2017) yang menyatakan bahwa tidak terdapat pengaruh yang signifikan antara CAR terhadap ROA.

\section{Pengaruh LDR Terhadap ROA}

Berdasarkan hasil penelitian terbukti bahwa variabel LDR tidak berpengaruh signifikan terhadap ROA sehingga Ho diterima.

Dilihat dari kenaikan dan penurunan LDR pada bank Bukopin yaitu ada sebagian nilai LDR berada pada batas bawah LDR, sehingga kondisi ini disebabkan pada kredit yang 
disalurkan oleh bank tidak banyak memberikan kontribusi laba karena kurang mengoptimalkan dana pihak ketiga, karena pada peningkatan LDR, mengakibatkan semakin rendahnya likuiditas bank tersebut karena jumlah dana yang diperlukan untuk membiayai kredit semakin besar.

Hasil penelitian ini juga sejalan dengan penelitian yang dilakukan oleh Deden Edwar Yokeu Bernardin (2016) dan Nasya Batari, A, P \& Ulil Hartono (2019), yang menyimpulkan bahwa LDR tidak berpengaruh terhadap ROA.

\section{Pengaruh NPL Terhadap ROA}

Berdasarkan hasil penelitian terbukti bahwa variabel NPL tidak berpengaruh signifikan terhadap ROA sehingga Ho diterima.

Rasio NPL yang tinggi mengindikasikan kondisi bank yang buruk pada kualitas kreditnya sehingga dapat menyebabkan resiko kredit yang dialami bank tinggi.

Dilihat dari kenaikan dan penurunan NPL dari tahun 2005-2018, terlihat bahwa selalu terdapat penurunan nilai ROA. Meskipun nilai ROA terlihat sebagian besar berada pada standar PBI yaitu maksimal 5\%, tetapi hal tersebut tidak berpengaruh pada profitabilitas bank, yakni setiap tahunnya selalu terjadi kredit macet, kurang lancar ataupun macet. Sehingga pada tahun-tahun terakhir nilai NPL sampai melebihi standar yang telah ditentukan. Dengan demikian adanya ketidakpastian antara kenaikan dan penurunan NPL yang diikuti dengan kenaikan dan penurunan ROA menyebabkan NPL tidak berpengaruh signifikan terhadap ROA.

Hasil penelitian ini sejalan dengan penelitian yang dilakukan oleh Husein Mismiwati (2016) dan Hasbi Ash Shidieq (2015) yang menyatakan bahwa tidak terdapat pengaruh yang signifikan antara NPL terhadap ROA.

\section{SIMPULAN}

Berdasarkan hasil penelitian, maka dapat ditarik beberapa kesimpulan berikut :

1. Variabel CAR, LDR, dan NPL berpengaruh terhadap ROA hanya sebesar 56\% dan sisanya sebesar $44 \%$ dipengaruhi oleh variabel lain.

2. Secara parsial tidak ada variabel independen (CAR, LDR, dan NPL) yang berpengaruh terhadap ROA. Sedangkan secara simultan variabel-variabel independen berpengaruh signifikan terhadap ROA.

\section{DAFTAR PUSTAKA}

Dr. Kasmir, S.E., M.M. , (2015), Manajemen Perbankan, Cetakan ketigabelas, PT Rajagrafindo Persada, Depok

Maulana, R., \& Kristanti, F. T. (2018). Pengaruh Car, Ldr Dan Npl Terhadap Profitabilitas Pada Industri Perbankan (studi Pada Bank Umum Nasional Dan Bank Swasta Yang Terdaftar Di Bursa Efek Indonesia Tahun 2012-2016). eProceedings of Management, $5(2)$.

Deden, E. Y., Bernardin (2016). Pengaruh CAR dan LDR Terhadap Return On Assets Analisis pada Bank BJB yang terdaftar di BEI periode 2009 - 2015. Jurnal Ecodomica, $6(2)$.

Hasdillah, (2017), Pengaruh Ldr, Npl, Nim dan Car terhadap Roa pada Bank Pembangunan Daerah Kalimantan Timur Periode 2010-2016. Jurnal Administrasi Bisnis, 5(4).

Husein, F., Muttaqin (2017). Pengaruh Car, Bopo, Npl Dan Ldr Terhadap Roa Pada Bank Konvensional Di Indonesia. Jurnal Administrasi Bisnis. 5(40), 1229-1240. 
Batari ayunda praja, n. A. S. Y. A., \& Hartono, U. (2018). Pengaruh ukuran perusahaan, Capital Adequacy Ratio (CAR), Loan To Deposit Ratio (LDR), Non Performing Loan (NPL) Terhadap Profitabilitas Pada Bank Umum Swasta Nasional Devisa Yang Terdaftar Di Indonesia Periode 2012-2016. Jurnal ilmu manajemen (jim), 7(1).

Mismiwati. (2016). Pengaruh CAR, NIM, BOPO, LDR Dan NPL Terhadap ROA Pada PT. BPD Sumsel Babel. I-Finance, 2(1).

Hasbi Ash Shidieq. (2015) Pengaruh Loan To Deposit Ratio, Non Performing Loan, Good Corporate Governance, Biaya Operasional Terhadap Pendapatan Operasional, Dan Capital Adequacy Ratio Terhadap Return On Assets Pada Bank Devisa Yang Go Public Periode 2010-2012. eProceedings of Management, 2(1).

Atmoko, A. S., Amboningtyas, D., \& Fathoni, A. (2018). Effect Of Ldr, Npl And Bopo On Profitabilities Based On Car (Case Study On Banking Companies Listed On The Indonesia Stock Exchange Period 2013-2017). Journal Of Management, 4(4). 